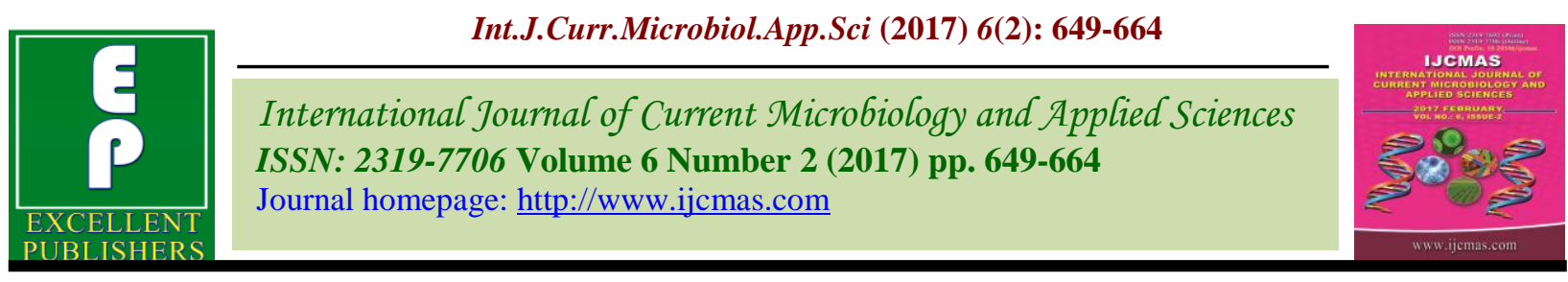

Review Article

http://dx.doi.org/10.20546/ijcmas.2017.602.074

\title{
Wax Degrading Bacteria: Scope and Applications in Agriculture
}

\author{
N. Arunkumar*, J. Gulsar Banu, N. Gopalakrishnan and A.H. Prakash \\ ICAR- Central Institute for Cotton Research, Regional Station, Coimbatore, \\ Tamil Nadu - 641003, India \\ *Corresponding author:
}

\section{A B S T R A C T}

\begin{tabular}{|l|}
\hline Ke y w or d s \\
Agriculture \\
residues, Insect pest \\
management, \\
$\begin{array}{l}\text { Water repellency, } \\
\text { Wax degrading } \\
\text { bacteria. }\end{array}$ \\
\hline Article Info \\
\hline $\begin{array}{l}\text { Accepted: } \\
\text { 18 January } 2017 \\
\text { Available Online: } \\
\text { 10 February } 2017\end{array}$ \\
\hline
\end{tabular}

Waxes are esters of long-chain fatty acids with long-chain fatty alcohols found abundant in the environment in various forms. Bacteria degrading these waxes in agricultural residues, soils and insects are gaining increased attention. In India, about 500 million tonnes of crop residues are generated annually and these crop residues are rich in cellulose, hemicellulose, lignin, pectin, cutin, waxes, fats and oils. Accumulation of waxy rich crop residues in the environment decreases the rate of decomposition and increase the hydrophobicity of soils. In turn, biodegradation of these abundant plant polysaccharides and neutral lipids of waxes and fats by suitable microorganisms could increase availability of nutrients and growth promoting substances in soil. Various wax degrading eubacteria genera, Pseudomonas, Alcaligenes, Micrococcus, Nocardia, Corynebacteria, Arthrobacter, Bacillus, Rhodococcus and Proteus capable of decomposing waxy rich residues are prevalent in the environment. Water repellency due to waxy coatings around soil particles could also be overcome by inoculation of selected biosurfactant producing, wax degrading bacteria in water repellent soils. Potential of wax degrading bacteria for control of wax coated homopteran insects like Aleyrodoidea (whiteflies); Aphidoidea (aphids) and Coccoidea (scale insects and mealybugs) is also being investigated from viewpoint of sustainable insect pest management.

\section{Introduction}

Application of wax degrading bacteria in agriculture focuses on three important phenomenon; decomposition of waxy rich agricultural residues, amelioration of water repellent soils and control of wax coated insect pests. Firstly, agricultural residue management with more emphasis on crop residue management is one of the important strategies in this direction. It is estimated that, the need of food grain in India would increase to 280 million tonnes by 2020 , which needs a lot of inputs including high yielding variety, inorganic and organic fertilizers, while newer approaches to enhance the agriculture production is need of the hour. Agricultural residues contain considerable amount of wax and rapid decomposition of wax rich crop residues by heterotrophic bacteria is hindered by chemical constituents of the residues. However, certain groups of bacteria are effective in wax degradation process resulting in addition of nutrients to the soil naturally. Waxes are hydrolysed by wax degrading microorganisms through pseudosolubilization, adherence, biosurfactant production, enzyme secretion and adsorption of waxes by direct contact. Fatimah et al., (2016) documented biosurfactant producing bacteria Arthrobacter 
sp. P2(1) utilizing hydrocarbon from petroleum contaminated soil and Kumar et al., (2015) isolated biosurfactants producing bacterial isolates characterized as Pseudomonas plecoglossicida, Lysinibacillus fusiformis and Bacillus safensis from oil contaminated soils. Samanta et al., (1986) reported heterotrophic nitrogen fixing bacteria Pseudomonas azotogensis, Xanthobacter flavus, Azotobacter paspali and Klebsiella pneumonia capable of utilizing jute leaf wax. Secondly, the emphasis is on water repellency: water repellency is a widespread phenomenon that occurs naturally due to accumulation of hydrophobic waxes or humic substances on soil particles. Inoculation of wax degrading bacteria in repellent soils under laboratory condition resulted in decrease of water repellency due to the biosurfactants produced by the bacterial isolates to utilize the wax compounds (Roper, 2004). Elisa et al., (2006) reported wax degrading bacteria from hydrophobic soils of Berlin, and the bacterial isolates were phylogenetically confirmed that they are Mycobacter vanbaalenii and Bacillus megaterium. In a recent novel approach, insect pest management is also possible with effective hydrocarbon degrading bacteria. Reduction in the wax content of certain insect pests like mealybugs through wax degrading microbial applications could be a potential biocontrol tool for mealybug control (Salunkhe et al., 2013).

This review sketches the current knowledge regarding wax degrading bacteria and suggests new approaches for the practical application of this elite group of microbes in sustainable agricultural production.

\section{Wax}

The term wax is derived from the AngloSaxon word weax, which means the natural material obtained from the honeycomb of the bee. Later on, the term wax is generally applied to all wax-like solids and liquids found in nature irrespective of their source or method of preparation, provided such constituents have wax like properties. The practical definition of a wax may therefore be "a substance similar in composition and physical properties to bees wax". Irrespective of their source, technically wax is nothing but esters of long-chain fatty alcohols with longchain fatty acids. The nature of the wax biochemical constituents i.e. hydrocarbons, sterol esters, aliphatic aldehydes, primary and secondary alcohols, diols, ketones, $\beta$ diketones and triacylglycerols vary greatly in composition with the origin such as mineral, marine, plant or insect. Generally, waxes are classified as commercial waxes (bees wax, jojoba, carnauba, wool wax or lanolin etc.), plant surface waxes, skin lipids, insect waxes, marine waxes, bird waxes and microbial waxes based on their origin and utilization purpose.

\section{Plant waxes}

The plant cuticle covers the epidermis of all aerial parts of plant organs as an uninterrupted extracellular matrix. It is hydrophobic in nature consisting mainly of the complex biopolymer, cutin and cuticular lipids called as waxes collectively (Fig. 1). The cuticle and cuticular waxes exhibit a multitude of functions including the major interfacial interactions. As plants cover much of the earth's surface, it seems likely that plant waxes are the most abundant of all natural lipids (Kolattukudy et al., 1976). Plant wax limits the diffusion of water and solutes, permitting a controlled release of volatiles that often deter pests or attract pollinating insects. The wax layer provides protection from diseases, insects and helps the plants to resist drought.

The major constituents of plant waxes are nalkanes $\left(\mathrm{CH}_{3}\left(\mathrm{CH}_{2}\right)_{\mathrm{x}} \quad \mathrm{CH}_{3}\right)$, alkyl esters $\left(\mathrm{CH}_{3}\left(\mathrm{CH}_{2}\right)_{\mathrm{x}} \mathrm{COO}\left(\mathrm{CH}_{2}\right)_{\mathrm{y}} \mathrm{CH}_{3}\right)$, fatty acids 
$\left(\mathrm{CH}_{3}\left(\mathrm{CH}_{2}\right)_{\mathrm{x}} \mathrm{COOH}\right)$, fatty alcohols $\mathrm{CH}_{3}\left(\mathrm{CH}_{2}\right)_{y} \mathrm{CH}_{2} \mathrm{OH}$, fatty aldehydes $\left(\mathrm{CH}_{3}\left(\mathrm{CH}_{2}\right)_{\mathrm{y}} \mathrm{CHO}\right)$, ketones $\left(\mathrm{CH}_{3}\left(\mathrm{CH}_{2}\right)_{\mathrm{x}} \mathrm{CO}\right.$ $\left.\left(\mathrm{CH}_{2}\right)_{\mathrm{y}} \mathrm{CH}_{3}\right)$, secondary fatty alcohols $\left(\mathrm{CH}_{3}\left(\mathrm{CH}_{2}\right)_{x} \mathrm{CHOH}\left(\mathrm{CH}_{2}\right)_{\mathrm{y}} \mathrm{CH}_{3}\right)$ and $\beta$ Diketones $\left(\mathrm{CH}_{3}\left(\mathrm{CH}_{2}\right)_{\mathrm{x}} \mathrm{COCH}_{2} \mathrm{CO}\left(\mathrm{CH}_{2}\right)_{\mathrm{y}} \mathrm{CH}_{3}\right)$ with carbon atom of 21-35, $34-62,16-32,22-$ $32, \quad 22-32, \quad 23-33, \quad 23-33$ and 27-33 respectively. The waxes also contain triterpenols constituted by sterols, $\alpha$-amyrin, $\beta$-amyrin, uvaol, lupeol, erythrodiol and triterpenoid acids, ursolic acid and oleanolic acid etc. In addition, hydroxy- $\beta$-diketones, oxo- $\beta$-diketones, alkenes, branched alkanes, acids, esters, acetates and benzoates of aliphatic alcohols, methyl, phenylethyl and triterpenoid esters are also present in the plant leaf wax. In palms and potato, wax crystals are more abundant on the leaves than on other parts. Grape leaf, rape leaf, apple fruit, rose flower, pea leaf and sugarcane stem were abundant with various hydrocarbons such as wax esters, aldehydes, ketones, primary and secondary alcohols and fatty acids (Hamilton, 1995). The lipid class and the nature and proportions of waxes greatly varied according to the plant species and the site of wax deposition in plant.

Chachalis et al., (2001) observed wax content of $22 \mu \mathrm{g} \mathrm{cm}^{-2}, 37 \mu \mathrm{g} \mathrm{cm}^{-2}$ in young leaves of red vine and trumpet creeper, respectively. English yew tree leaves composed of $34.1 \mu \mathrm{g}$ $\mathrm{cm}^{-2}$ wax, with $21 \%$ fatty acids, $15 \%$ phenyl esters and 9\% secondary alcohols with lesser percentage of aldehydes, primary alcohols, alkanes, alkanediols, alkyl esters and tocopherols. Kocha et al., (2005) observed the wax content in Brassica oleracea, Tropaeolum majus and Eucalyptus gunnii as $23.1 \mu \mathrm{g} \mathrm{cm}^{-2}, 76.9 \mu \mathrm{g} \mathrm{cm}^{-2}$ and $66.9 \mu \mathrm{g} \mathrm{cm}^{-2}$, respectively. Natural wax is also found on the surface of fruits as tiny crystals which can be identified through electron microscope. Epicuticular waxes on the surface of fruits render protection against biotic and abiotic stresses. The wax crystalline shape varies with the species and the waxy bloom found on fruit surfaces is due to wax crystals. It renders water repellency to the fruit surface and reduces water permeability through the skin. Cuticular waxes of tomato fruits and apple fruits play a major role in limiting transpirational water loss across the fruit surface. The leaves of cotton are sheltered with an amorphous layer of cuticle with plentiful epicuticular wax ridges on the upper and lower surfaces (Wullschleger and Oosterhuis, 1989). The wax layer thickness in cotton leaf is about $30 \mu \mathrm{m}$, and this thickness has been found to increase with dehydration treatment. The water stress increases the wax deposition on the leaf, bract and boll of cotton that act as barrier against non-stomatal water loss. Bondada et al., (1996) reported increase in the wax concentration due to water stress in cotton leaf, bract and boll by $68.57 \%, 46.8 \%$ and $4.1 \%$, respectively.

\section{Waxes in crop residues}

Crop residues are abundant with cellulose, hemicellulose, lignin, pectin, chitin and wax. According to NRCS 2000, green plant residues comprise: $45 \%$ cellulose, $20 \%$ hemicellulose, $20 \%$ lignin, $8 \%$ proteins, sugars and starches (5\%) and $2 \%$ fats and waxes. Rice straw consists of $43.30 \%$ cellulose, $26.40 \%$ hemicellulose, $16.29 \%$ lignin, $12.26 \%$ ash and $2.18 \%$ waxes (Elmarsy, 1983). Sugarcane bagasse consists of $42 \%$ cellulose, $25 \%$ xylan, $25 \%$ lignin and $1 \%$ waxes. Sugarcane wax contains $70-72 \%$ wax esters of which $20 \%$ myricyl palmitate, $1-2 \%$ myricyl myricinate, $37-38 \%$ stigmasteryl palminate, $13 \%$ phytosteryl dihydroxypalmitate and $14 \%$ free fatty acids. The stigmasterol and sitosterol constituted about $2 \%$ and $0.77 \%$ of the total wax of sugarcane. Morrison et al., (1981) studied the wax content of sunflower seed and found that sunflower seed hull accounts for higher 
percentage of wax (3\%), which is composed of long chain fatty esters, free fatty acids and free fatty alcohols. The seeds of soyabean (Gylcine max), celery (Apium graveolens) and sesame (Sesamum indicum) contain waxes of about $0.5,0.2$ and 0.3 per cent, respectively. Gniwotta et al., (2005) reported that the wax content of Pisum sativum leaves was 14 to $26 \mu \mathrm{g}$ $\mathrm{cm}^{-2}$ of which higher percentage is accumulated in the epicuticular layer. Ortwin et al., (2005) have studied lipid content of corn and wheat germ and found that corn germ recorded higher lipid content of $30.7 \%$ than wheat germ. Natural waxes in crop residues contain a wide variety of simple components such as hydrocarbons, esters, fatty acids, ketones, mono-di-tri acylglycerols and sterol esters (Kolatttukudy et al., 1976). Several growth promoting substances like policosanol, tetracosanol, hexacosanol and triacontanol are associated with most of the plant waxes. Corn wax consists of hentriacontane, myricyl tetraconsanate, myricyl isobehenate, sitosterol and stigmasterol, whereas sunflower seed wax is dominated with ceryl cerotate. The presence of n-triacontanol in apple cuticle wax, sugarcane wax, beeswax and carnauba wax has been reported in many literatures. Chibnal et al., (1974) showed that lucerne leaf or alfalfa is a source of n-triacontanol $\left(\mathrm{CH}_{3}\left(\mathrm{CH}_{2}\right)_{28} \mathrm{CH}_{2} \mathrm{OH}\right)$ or "melissyl" or myricyl alcohol.

\section{Insect waxes}

An insect's exoskeleton (integument) serves as a protective covering over the body, as a surface for muscle attachment, a water-tight barrier against desiccation, and a sensory interface with the environment. It is formed of a multi-layered structure with four distinctly functional regions: epicuticle, procuticle (exocuticle and endocuticle), epidermis, and basement membrane (Fig. 2). The epicuticle is the outermost part of the cuticle. Its function is to reduce water loss and block the invasion of foreign matter. The innermost layer of epicuticle is often called the cuticulin layer, a stratum composed of lipoproteins and chains of fatty acids embedded in a proteinpolyphenol complex. An oriented monolayer of wax molecules lies just above the cuticulin layer; it serves as the chief barrier to movement of water into or out of the insect's body. The eggs of some insects (Rhodnius prolixus, Ixodes ricinus and Argas reflexus) have a wax layer, supported by a tanned protein substrate, on the inner surface of the shell layers; this wax layer protects the eggs from desiccation. Their properties are identical to those of the cuticular wax layers and show sharp transition points. The study of insect cuticular waxes dates back from Beament (1945), in his brief investigation of insect waxes, measured the thickness of this wax layer of a variety of insects by extracting the cuticle with chloroform, weighing the extracted wax and relating this quantity, expressed as a volume, to the total surface area of the sample found thickness of the layers to be between 0.2 to $0.3 \mu$ thick.

Among the insect wax, bees wax (Cera alba) is most significant and for an extensive period of time, word wax meant only bees wax, the most important insect wax. Beeswax generally refers to wax of the European bee, Apis mellifera, formed into "scales" by eight wax-producing glands in the abdominal segments 4 through 7 of worker bees, and used to form cells for honey-storage and larval and pupal protection within the beehive. Another major group of wax producers is the scale insects, of the order Hemiptera, suborder Sternorrhyncha previously placed in group called "Homoptera". Scale insects can be roughly divided into two groups: armored scales and soft scales. Armored scales are so named because they secrete a protective cover over their bodies. Tulloch (1970) reported that the biochemical composition vary with the 
species of the insects (Table 1). Except for the adult males and crawlers, armored scale live inside a protective covering made of waxes and previously molted skins. This covering helps protect scale from natural enemies, pesticides, and desiccation. Soft scales secrete a layer of wax that covers their bodies. As with the armored scale, this wax layer protects them also from natural enemies, pesticides, and desiccation.

Another major group of waxy insects are the mealybugs which fall under the order Hemiptera, sub order Sternorrhyncha. The suborder Sternorrhyncha contains four superfamilies: Psylloidea (jumping plant lice); Aleyrodoidea (whiteflies); Aphidoidea (aphids) and Coccoidea (scale insects and mealybugs). Mealybugs are very soft-bodied, sap feeders with mouthparts adapted to piercing and sucking and secrete powdery covers all over the body. Wax deposits were maximum and thickest on the adult females, particularly the oldest. The powdery waxy coating protects the mealybugs from desiccation and penetration of toxic chemicals and pathogens through the integument (Watson and Kubiriba, 2005). Salunkhe et al., (2013) standardized the wax extraction procedure for mealybugs and obtained $4.1 \mathrm{mg}$ of solid wax form pink mealybug Maconellicoccus hirsutus. These waxes are in the form of filaments or particles and are also found in many whitefly species. In sweetpotato whitefly, Bemisia tabaci, the waxes are composed of the C34 equivalents tetratriacontanol and tetratriacontanol (Nelson et al., 1999). The knowledge on chemical composition of plant and insect waxes raise doubts about the correlations that exists between these two types. Even though plant and insect waxes are mixtures of aliphatic hydrocarbons and their derivatives, plant hydrocarbons may contain secondary metabolites such as triterpenoids, phenylpropanoids, and flavonoids, whilst insect hydrocarbons, may include saturated, unsaturated and methyl-branched hydro carbons (Nguyen et al., 2014).

\section{Wax in soil}

Schnitzer (1972) reported that soil organic matter is a complex mixture containing organic humic substances consisting of amino acids, carbohydrates and lipids inherited from the decay of plants and animals. Soil organic matter can be separated into two groups of compounds which is a series of brown to black, high-molecular weight polymers formed by secondary synthesis reactions and non humic substances. Incorporation of lignin and waxy rich plants such as lucerne and soybean decrease the rate of decomposition and increase the hydrophobicity of soil. Decomposed plant material itself produces substances that glue soil particles together. These substances include slime, mucus and fungal mycelia, which contain gums, waxes and resins which aggregate soil particles, thereby enhancing the tilth, porosity, and water holding capabilities of soil. The lipids of aerobic soil probably exist in low and variable quantities as remnants of microbial cells, which may be associated with undecomposed plant residues and the bodies of living and dead micro faunal organisms (Franco et al., 2000a).

Waxes are adsorbed on soil humic substances by hydrophilic - hydrophobic interactions. Soil waxes are chiefly esters of the higher numbers of homologous n-acids and n-alcohols which is in agreement with the animal and plant waxes. The prairie soil humus contains 1.2 $6.3 \%$ of fats, waxes and resins. Negative impact of wax on organic matter was observed in soil due to hydrophobic waxes accumulation along with humic and fulvic acid and other long chained organic compounds. Soil organic matter is accumulated with $2 \%$ wax content which deposit along with minerals and cause water 
repellency. Water repellency is primarily caused by a skin around soil particles of waxes consisting of branched and unbranched $\mathrm{C}_{16}$ to $\mathrm{C}_{36}$ fatty acids and their esters, alkanes, alcohols, and sterols (Morley et al., 2005). Hydrophobic waxes in soil were obtained from plant residues which can coat sand grains, thereby influencing the hydraulic behavior of the soil (Nicolau et al., 1996). Reduction in crop yield, delayed germination, poor stand establishment and increased risk of erosion from wind and water is caused due to water repellency.

\section{Wax degrading bacteria}

Utilization of hydrocarbon as a sole source of carbon and energy by soil microorganisms was reported by Perry and Scheld (1968) who also found that soil from oil fields contain higher number of microbial population that utilize petroleum hydrocarbons. Leifsonia sp. with the potential to utilize higher alkanes like paraffinic crude oil was confirmed by Gas chromatography (Patel et al., 2015). Seven strains of bacteria categorized as Acinetobacter, Neisseria, Plesiomonas, Xanthomonas, Zoogloea, Flavobacterium and Pseudomonas capable of utilizing normal octane, paraffin wax, benzene, methyl benzene, phenol and naphthalene as the sole carbon source were isolated from oil wells in the northern region of the Shaanxi province, China (Xu et al., 2013). Ridgway et al., (1990) documented hydrocarbon utilizing eubacteria genera as Pseudomonas, Alcaligenes, Micrococcus, Nocardia, Corynebacteria, Arthrobacter, Bacillus, Rhodococcus and Proteus. Roper (2004) isolated wax degrading microorganism from soil with whale oil, sheep camp, abattoir, sewage effluent, composted animal manure, sewage, animal fats and they were phylogenetically confirmed that they belong to Bacillus sp., Pseudomonas sp. and Actinomycetes. Arunkumar et al., (2016) documented the diversity of aerobic wax degrading bacterial isolates associated with cotton mealybugs and identified the strains as Bacillus sp. PSAD1, Pseudomonas sp. PSAD2, Enterobacter sp. PSAD3, Bacillus sp. PSAD5, Pseudomonas sp. PSAD6, Bacillus sp. PSAD7, Bacillus sp. PSAD8 and Serratia sp. PSAD9 based on their lipase and biosurfactant activity. Samanta et al., (1986) established utilization of jute leaf wax by nitrogen fixing microorganisms by growing in medium containing $0.025 \%$ yeast extract and jute or coconut leaf wax as the sole carbon source and the leaf wax utilizing bacteria was identified as Pseudomonas azotogensis, Xanthobacter flavus, Azotobacter paspali and Klebsiella pneumoniae. Markossian et al., (2008) have reported efficient lipid-degrading bacterial isolates from hot spring that utilize palmitic acid, stearic acid, lanolin, olive oil, sunflower seed oil, soya oil and fish oil as sole carbon and energy source. Elisa et al., (2006) reported wax degrading bacterial isolates from hydrophobic soils of Tiergarten Park in Berlin, and bacterial isolates were phylogenetically confirmed that they are Mycobacter vanbaalenii and Bacillus megaterium. Ruiz et al., (2004) demonstrated efficient lipid degradation of alkalophilic bacteria Bacillus subtilis from Argentina forest soil. Many of the phylloplane bacteria including species of Xanthomonas, Flavobacterium, Pseudomonas and Erwinia, Corynebacterium, Lactobacillus and Bacillus (Lynch and Hobbie, 1988) are able to degrade the n-alkane components of waxes.

\section{Mode of action of wax degrading bacteria}

A wide variety of microbes are able to use long chain hydrocarbons as their sole source of carbon and energy, mostly by following two oxidation pathways (Baker, 1994) (Fig. $3)$. The first and the most accepted is the monoterminal oxidation pathway initiated by monoxygenase yielding an alcohol 
intermediate which is oxidized further to an aldehyde and then to an acid. The second pathway, monoterminal oxidation yielding an n-alkyl hydroperoxide which is then converted to a peroxy acid, an aldehyde and finally to an acid. There are two problems associated with the biodegradation of wax by microorganisms; the insoluble substrate cannot enter the cells and the cells do not produce the necessary enzymes needed to metabolize the hydrocarbons of wax. But few microbes that grow using hydrocarbons showed the ability to accumulate the substrate intracellularly as inclusion bodies. The uptake of the solid n-alkanes by microorganisms occurred through transport across the cell membrane (Samanta et al., 1986). Adherence is an important phenomenon for hydrocarbon utilization by microorganisms. Adherence is directly related to the hydrophobicity of the microorganisms and specialized structures like thin fimbriae present in the bacterial cell determine the adherence potential. Husain et al., (1997) showed that a Pseudomonas nautica grew on solid n- alkane (eicosane) by adapting morphological changes in filamentous structure which provides a threefold increase of adherence of the cells.

Apart from this, wax degrading microorganisms also produce biosurfactants to utilize wax and their compounds. Biosurfactants are surface-active components secreted by certain microorganisms to increase the surface area of hydrophobic substrates for enhanced utilization. Sakthipriya et al., (2015) demonstrated biosurfactant producing Pseudomonas aeruginosa and Pseudomonas fluorescens with waxes as sole source of carbon. Rocha et al., (1992) isolated biosurfactant producing bacteria Pseudomonas aeruginosa which are capable of degrading crude oil. Singer and Finnertly (1990) isolated and characterized Rhodococcus sp. from oil enriched soil and observed biosurfactant activity. Enzymatic studies revealed that a microorganism must have the ability to produce degrading enzymes such as lipases to catabolise the long-chain hydrocarbons. Microbial lipases are produced by yeast, fungi, and bacteria as extracellular, intracellular and cell-bound enzyme which breaks the wax in crop residues. Lipases catalyse both hydrolysis and synthesis of esters from glycerol and longchain fatty acids. Fairolnzia et al., (2007) reported that a thermophilic bacterium Bacillus sp. strain L2 produces an extracellular lipase enzyme to utilize long chain alkanes. Haba et al., (2000) isolated Pseudomonas, Bacillus, Candida, Rhodococcus and Staphylococcus that grow on waste oils with excellent lipolytic activity.

\section{Scope and applications in agriculture}

\section{Agricultural residues decomposition}

Crop residues sustain soil health by maintaining physical and chemical condition of soil. Crop residues are good sources of plant nutrients and are important components for the stability of agricultural ecosystems. Large quantities of crop residues are left in the field, which can be recycled for nutrient supply. The biomass residues generated in India are, field based residues (rice straw, wheat straw, maize stalks, cassava stalks, sugarcane tops, cotton stalks etc.), process based residues (rice husk, wheat straw, maize cob/husks, coconut shells, sugarcane baggase etc.), forestry-based wood residues (solid and dust from saw milling and plywood industries etc.), agro-based wood residues (cocoa tree prunings, coconut tree fronds etc.).

In India, agricultural residues constitute a major part of the total annual production of biomass residues and in particular 500 million tonnes of field based residues are generated annually. Their chemical composition and availability (Table 2) varies with the crop 
(Shaikh et al., 2015). Little is known about the consumption of residues for various beneficial purposes. The lack of knowledge is due to the scattered nature of the residue generation, its seasonality and differences in local situations including availability of equipment, environmental conditions. In general, the residues are used as fuel, but a large amount is burnt in the field. The crop residues are abundant with cellulose, hemicellulose, lignin, pectin and also contain a low amount of diverse group of substances like protein, waxes and fatty acids. The decomposition of wax rich crop residue like rice straw $(2.18 \%)$, sunflower residues $(3 \%)$, Soyabean $(0.5 \%)$, Sugarcane bagasse $(1 \%)$ provides major and micro nutrients and also releases growth promoting substances. Microbial decomposition of crop residues plays an important role in maintaining the soil health because it recycles plant nutrients. Biodegradation of these ubiquitous crop residues with suitable microorganism facilitates nutrient from crop residues and maintain sustainable soil fertility and health. Incorporation of plant residues in agricultural systems and enrichment of their decomposition with elite microorganisms will improve the soil fertility (Alguacil et al., 2008).

Apart from microbial lipases, wax degrading microorganisms produce cellulase, amylase and xylanase enzymes for effective decomposition of plant residues. Various studies have shown that composting of organic waste with microorganisms accelerates organic matter stabilization and gives a product rich in chelating and phytohormonal elements (Tomati et al., 1995). Kumar et al., (2010) reported that composting of wax rich waste by-products of the sugarcane industry, bagasse, pressmud and trash by bioinoculation followed by vermicomposting resulted in value added disposal of waste materials.

\section{Growth promoting substances}

Fatty alcohols like Policosanol (C20-36), docosanol (C22), tetracosanol (C24), hexacosanol (C26), octacosanol (C28), and triacontanol $(\mathrm{C} 30)$ are present ubiquitous as constituent of cuticular waxes of major agricultural crops (Kolattukudy and Watson, 1973). Environmental transformations of alkanes and waxes may be mediated by bacteria and these reactions yield alcohol intermediates (Roper, 2004). The bacterial (Pseudomonas oleovorans and Acinetobacter sp. strain M-1) alkane hydroxylase system produce enzymes like alkane hydroxylase $(\mathrm{AlkB})$, rubredoxin $(\mathrm{AlkG})$ and rubredoxin reductase (AlkT) resulted in fatty alcohol synthesis (Ishige et al., 2003). Ries et al., (1977) stated that triacontanol $\left(\mathrm{CH}_{3}\right.$ $\left.\left(\mathrm{CH}_{2}\right)_{28} \mathrm{CHOH}\right)$ is a straight chain fatty alcohol of thirty carbon atoms $\left(\mathrm{C}_{30}\right)$ has been recognized as prominent chemical for plant growth promotion of many agricultural and horticultural crops with great stimulatory effect on various processes including growth and enhancing protein content. Triacontanol obtained from wax breakdown is a natural growth promoting substance that enhanced growth rates and yield of many crops (Ivanov and Angelov, 1997).

\section{Amelioration of water repellent soils}

Water repellency is the accumulation of hydrophobic waxy coatings around soil particles produced by roots, surface waxes from plant leaves, decomposed organic matter and soil biota, particularly fungi (Fig. 4). These compounds are strongly hydrophilic when wet, but below a critical moisture threshold, the hydrophilic ends of this amphiphilic compounds bond strongly with each other and soil particles, leaving an exposed hydrophobic surface that induces water repellency. 
Severe soil water repellency is widespread and affects land used for agriculture. Ritsema et al., (1997) reported that repellency causes uneven infiltration of water into soil. Franco et al., (2000a) reported the most problematic areas of south-western Australia, where over two million hectare soil recorded very low yield due to water repellency. Water repellency reduces crop and pasture yields through delayed germination, poor stand establishment and increased risk of erosion from wind and water. Different approaches exist to ameliorate soil water repellency; such as physical (tillage, addition of clay), chemical (application of wetting agents) and biological (increasing wax degrading bacterial population) but the first two approaches provide only short-term positive impacts wherein, the third approach shows long-term impacts (Hallett, 2008). The biological phenomenon was demonstrated by Roper (2004) to manage water repellency and isolated a number of bacteria (Roseomonas sp., Mycobacterium sp. Nocardia sp. Rhodococcus spp.) including Actinomycetes that are able to utilize waxes as sole carbon sources and inoculation of these waxdegrading bacteria in water repellent soils under controlled laboratory conditions improved soil wettability. Again in 2005, Roper confirmed through field experiments that the addition of lime to sands reduced water repellency and enhanced the waxdegrading bacterial population in the soil. Biosurfactants produced by the wax degrading microorganisms emulsify hydrocarbons from soil surfaces and improve the efficiency of microbial degradation and reclamation of water repellent soils. Reclamation process combining both chemical and microbial process is also successful. Laboratory and glasshouse experiments conducted in water repellent sands with slow-release sources of nitrogen and phosphorus fertilizers resulted in a significant drop in hydrophobicity due to stimulation of indigenous wax-degrading microorganisms already prevalent in the soil (Franco et al., 2000b).

\section{Control of insect pests}

The major competitors with humans for resources generated by agriculture are the insect pests (Oerke and Dehne, 2004). The damage caused by insect pests is one of the most important factors resulting in reduced productivity of agricultural crops. Losses can occur both in field (pre-harvest) and during storage (post-harvest). Agricultural losses caused by insects are huge as the damage caused depends on the environment, plant species, farmer's socioeconomic conditions and technology level used. Apart from the economic losses caused by the direct action of insect pests, indirect economic losses related to the purchase and application of insecticides, expenses related to medical treatment for people poisoned by insecticides, and to rectify damage caused to environment also occurs. The major components in the cuticular extracts of insects include hydrocarbons, wax esters, aldehydes, ketones, alcohols and acids. The homopteran insects produce large amounts of wax (Nelson et al., 1999), which protects them from target chemicals resulting in higher insecticide consumption.

Repeated use of chemical insecticides for a long time has disrupted biological control by natural enemies leading to frequent pest outbreaks and development of resistance in major insect pests. This indicates the need to develop new and selective insect control alternatives of biological origin, particularly for insects with waxy rich cuticle. Also biopesticide formulations are specific to a target pest and it offers an ecologically sound and effective solution to pest problems. The most widely used microbial control agent is Bacillus thuringiensis (Bt). Today numerous 
bacterial isolates are commercially produced with activity against insect as well as fungal pests. A recent survey states that more than 300 microbial insecticide products have been registered recently in China, out of which $B$. thuringiensis constitute 276 products (Huang et al., 2007) highlighting the success of biopesticides.

Success in bacterial insect pathogens is primarily related to the significant identification and utilization of the organisms to control pest insects. Microbes produce cell wall degrading enzymes viz., chitinase, lipase, protease, $\beta$-1,3-glucanase, chitin deacetylase and chitosanase as a lethal component against insect pests. Lipases are hydrolytic enzymes with diversified activities including cutinase, phospholipase, cholesterol esterase, isophospholipase, amidase and other esterase (Sharma et al., 2016) for effective breakdown of complex structures. The lipase enzyme plays a major role in the separation and hydrolysis of the insect waxy mass making the cuticle accessible to degradation by chitinases and proteases.

Table.1 Yields per cent of hydrolysis products of scale insect waxes

\begin{tabular}{|lcccc|}
\hline \multicolumn{1}{|c}{ Insect } & Hydrocarbons & Alcohols & N-acids & Hydroxyl acids \\
\hline Gascardia madagascariensis & 0.6 & 28.0 & 38.0 & 33.4 \\
Coccus ceriferans & 2.6 & 47.4 & 50.0 & 0 \\
Tachardia lacca & 1.8 & 77.2 & 21.0 & 0 \\
Icerya purchasi & 26.9 & 32.3 & 31.4 & 9.4 \\
Ceroplastes rusci & 11.8 & 23.6 & 64.6 & 0 \\
Pulvinaria flocifera & 8.3 & 39.2 & 32.2 & 20.3 \\
Quadraspidiotus perniciosus & 9.8 & 14.7 & 75.5 & 0 \\
\hline
\end{tabular}

*(Sourced from Tulloch, 1970)

Table.2 Chemical composition and availability of some major crop residues in India

\begin{tabular}{|ll|ccccc|c|}
\hline \multirow{2}{*}{ Crop } & \multirow{2}{*}{$\begin{array}{c}\text { Crop } \\
\text { residue }\end{array}$} & Cellulose & Pentosan & Lignin & $\begin{array}{c}\text { Chemical composition }(\%) \\
\text { Blcohol } \\
\text { Annual } \\
\text { extractives }\end{array}$ & $\begin{array}{c}\text { Assh } \\
\text { availability/year } \\
\text { (million tonnes) }\end{array}$ \\
\hline Cotton & Stalks & 41.93 & 18.99 & 27.18 & 9.30 & 7.00 & 30 \\
Sugarcane & Bagasse & 40.00 & 22.60 & 14.84 & 15.92 & 4.94 & 28 \\
Rice & Husk & 44.06 & 17.85 & 17.20 & 3.40 & 16.68 & 48 \\
Wheat & Straw & 41.36 & 20.36 & 12.06 & 5.63 & 4.43 & 5 \\
Pigeon & Straw & 39.6 & 24.00 & 16.90 & 7.30 & 7.00 & 40 \\
pea & Stalk & 41.95 & 10.32 & 29.70 & 3.28 & 1.98 & 6 \\
Maize & Stalk & 43.39 & 19.58 & 22.82 & 9.34 & 3.36 & 35 \\
Groundnut & Cobs & 36.08 & 27.90 & 11.10 & 14.60 & 4.00 & 5 \\
Linseed & Stalks & 36.55 & 13.94 & 31.28 & 12.24 & 4.43 & 5 \\
\hline
\end{tabular}

*Select crop residues details only presented (Sourced from Shaikh et al., 2015) 
Table.3 Lipase enzyme activities of Myrothecium verrucaria, Metarhizium anisopliae and Bacillus sp. with mortality of Ceratovacuna lanigera of sugarcane

\begin{tabular}{|l|c|c|}
\hline \multicolumn{1}{|c|}{ Organism } & $\begin{array}{c}\text { Lipase } \\
\text { (U/ml) }\end{array}$ & $\begin{array}{c}\text { Mortality of } \\
\text { Ceratovacuna lanigera }(\%)\end{array}$ \\
\hline Myrothecium verrucaria & 1.0 & $73 \pm 3$ \\
\hline Bacillus sp. B1 & 1.0 & $54 \pm 4$ \\
\hline Metarhizium anisopliae & 1.0 & $59 \pm 2$ \\
\hline Commercial lipase & 2.0 & $32 \pm 3$ \\
\hline $\begin{array}{l}\text { M. verrucaria enzyme }+ \\
\text { M. anisopliae conidia }\end{array}$ & 1.0 & $96 \pm 3$ \\
\hline
\end{tabular}

*(Sourced from Chavan, 2009)

Fig.1 Diagram illustrating layers and composition of mature leaf

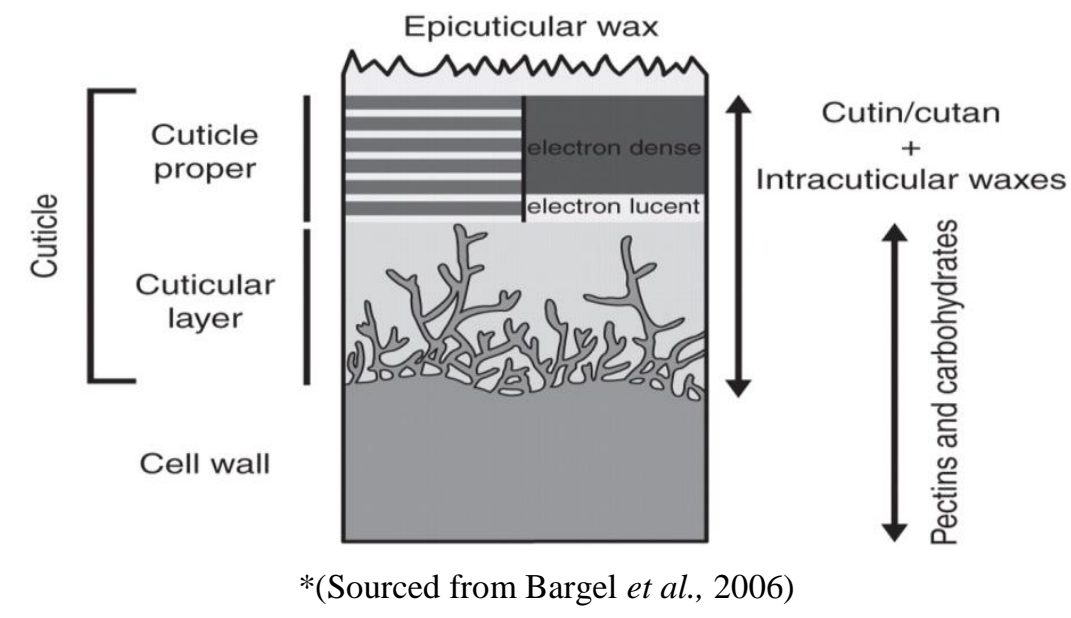

Fig.2 Stratification of the outermost layers of insect cuticle

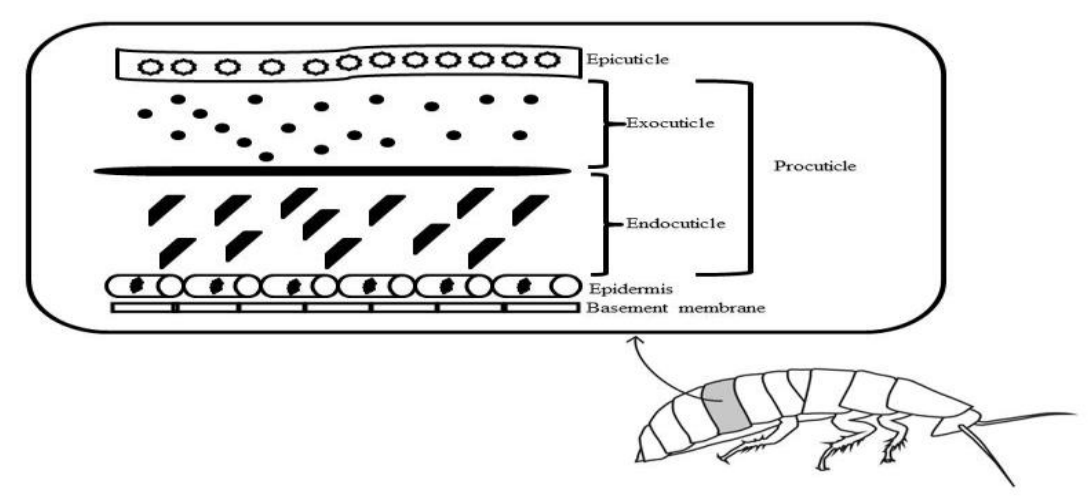


Fig.3 Oxidation pathways for the metabolism of long chain hydrocarbons

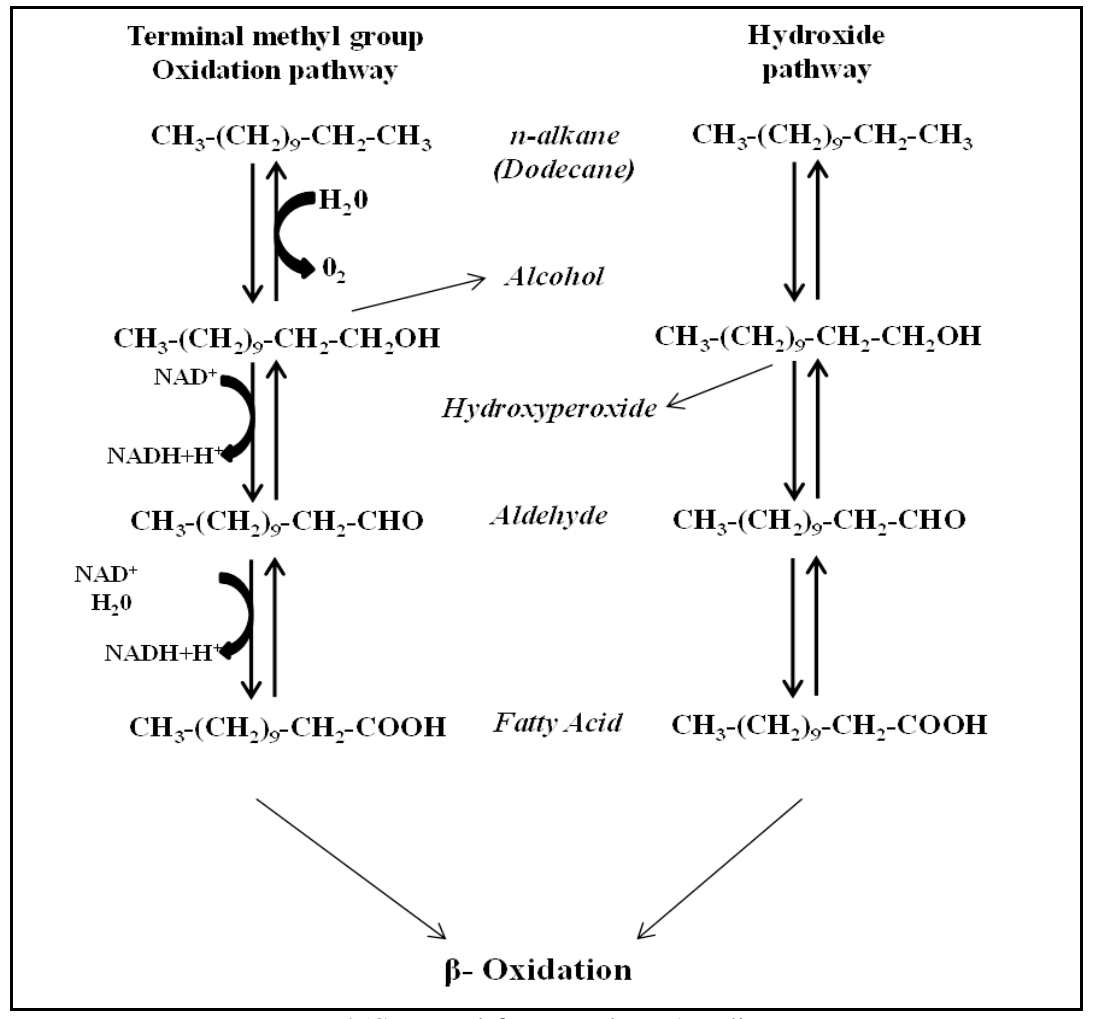

*(Sourced from Baker, 1994)

Fig.4 Origin of water repellency in soil

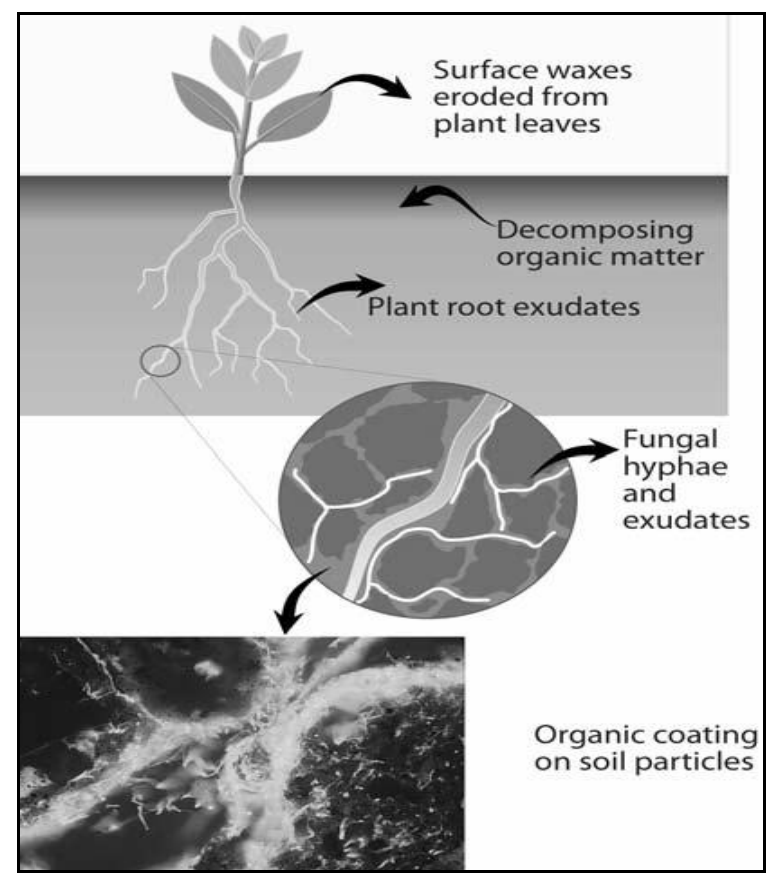


The mortality of Ceratovacuna lanigera (wolly aphid) of sugarcane under laboratory conditions increased several fold due to the microbial lipases of Myrothecium verrucaria, Metarhizium anisopliae and of Bacillus sp. B1 (Table 3).

Myrothecium verrucaria produces chitinase, lipase, protease and $\beta$-1,3-glucanase (Shaikh and Deshpande, 1993) that killed both first (I) and fourth (IV) instar Aedges aegypti mosquito larvae, within $48 \mathrm{~h}$ of application (Mendonsa et al, 1996). Entomopathogenous fungi such as Beauveria bassiana and Metarhizium anisopliae that can grow on long chain alkanes (up to C33) as well as many fatty acids, alcohols, and triacylglycerides were reported in many literatures. The conidial suspension of Cladosporium cladosporioides with significant lipase activity to degrade the waxy ovisac, could be one of the potential tool for the control of cotton mealybug (Banu, 2014). An excellent report on the efficacy of wax degrading bacteria on insect pests control was by Salunkhe et al., (2013), in their investigation against polyphagous insect pest, the pink mealybug, Maconellicoccus hirsutus. The bacterial isolates originating from $M$. hirsutus cadavers were screened for their wax degrading effects and the three most potent wax degrading isolates were identified to be Serratia marcescens, Pseudomonas aeruginosa and Bacillus subtilis. Application of these wax degrading bacterial isolates reduced female longevity, offspring production as well as reduction in weight and wax content of emerging mealybug adults.

In conclusion, extensive use of chemical pest control agents is regarded as ecologically unacceptable in all countries. Now, it is time to replace them gradually with biopesticides with various biological activities that occur naturally from living organisms. Biopesticides based on microbes as whole, microbial toxins, biochemicals derived from micro-organisms are emerging faster but the potential of certain group of microbes still remains unexplored. The review underscores the potential of wax degrading bacteria in plant residue decomposition, reclamation of problematic soils and importance in insect pest control. Wax degrading bacteria can provide an ecofriendly solution for major problems of agriculture mainly in control of polyphagous insect pests like mealybugs and aphids. Further investigations by means of laboratory experiments and field studies are underway by the authors for efficacious application of newer wax degrading microorganisms in integrated pest management on commercially viable scale.

\section{Acknowledgment}

The Financial assistance to Dr. N. Arunkumar in the form of SERB National Post-Doctoral Fellowship (File Number: PDF/2015/000844) from Science \& Engineering Research Board (SERB), Department of Science and Technology, Government of India and institutional support by ICAR- Central Institute for Cotton Research (CICR), Nagpur, Maharashtra, India are gratefully acknowledged.

\section{References}

Alguacil, M.D., F. Caravaca, R. Azcón and. Roldán A.2008. Changes in biological activity of a degraded Mediterranean soil after using microbially-treated dry olive cake as a biosolid amendment and arbuscular mycorrhizal fungi. Eur. J. Soil. Biol., 44: 347-354.

Arunkumar, N., J.G. Banu, N. Gopalakrishnan and Prakash A.H. 2016. Isolation and characterization of wax degrading bacteria isolated from cotton mealy bugs for their application in sustainable agriculture production. Extended abstract for Fifth International Conference on Sustainable Utilization of Tropical Plant Biomass: 
Bioproducts, Biocatalysts and Biorefinery (SutB4), TNAU, Coimbatore. pp.153-155.

Baker, K.M., 1994. Bioremediation. McGrawHill., New York, p. 31.

Banu, J.G., 2014. A novel method for the management of mealybug in cotton. Proceedings of $3^{\text {rd }}$ International Conference on Agriculture and Horticulture held at Hyderabad International Convention Centre, Hyderabad. pp.104.

Bargel, H., K. Koch, Z. Cerman and Neinhuis C. 2006. Structure-function relationships of the plant cuticle and cuticular waxes - a smart material?. Funct. Plant Biol., 33: 893-910.

Beament, J.W.L.1945. The cuticular lipoids of insects. J. Exp. Biol.,21: 115-131.

Bondada, B.R., D.M. Oosterhuis, J.B. Murphy and Kims K.S. 1996. Effect of water stress on the epicuticular wax composition and ultrastructure of cotton (Gossypium hirsutum L.) leaf, bract and boll. Environ. Exp. Bot., 36: 61-69.

Buckner, J.S., M.C. Mardaus and Nelson, D.R. 1996. Cuticular lipid composition of Heliothis virescens and Helicoverpa zea pupae. Comp. Biochem. Physiol., 114(2): 207-216.

Chachalis, D., K.N. Reddy and Elmore C. D. 2001. Characterization of leaf surface, wax composition of redvine and trumpet creeper with glyphosate. Weed Sci. Soc. Ame., 49: 156-163.

Chavan, S., 2009. Biocontrol of insect pests in agriculture using chitinolytic enzyme complex of Myrothecium verrucaria. Ph.D Thesis, National chemical laboratory, Pune, India.

Chibnal, A.C., E.F. Williams, A.L. Latner and. Piper S.H 1974. The isolation of nTricontanol from Lucerne wax. J. Biochem., 25: 75-83.

Elisa, D., U. Boeckelmann, B. Braun, D. Diehl, G.E. Schaumann and Grohmann E.2006. Wax-degrading bacteria influence water repellency of soil. Biores. Technol., 50: 1-12.

Elmasry, H.G. 1983. Utilization of egyptian rice straw in production of cellulase and microbial protein: Effect of various pre-treatments on yields of protein and enzyme activity. J. Sci. Food Agric., 34:725-732.

Fairolniza, M., T. Leow, A.D. Mukred, A., Bakar,
M. Basri, R. Raja and Rahman A. 2007. Production of lipase by Bacillus sp. strain L2: nutritional and physical factors. J. Basic Microbiol., 47: 406-412.

Fatimah, S., Ardyati, T., zahroh, N., Baktir, A and Thontowi A. 2016. Identification and Characterization of biosurfactant producing bacteria Arthrobacter sp. P2. J. Pure Appl. Microbiol., 10(1):151-156.

Franco, C.M.M., P.J. Clarke, M.E. Tate and Oades, J.M. 2000a. Hydrophobic properties and chemical characterisation of natural water repellent materials in Australian sands. J. Hydro., 231/232: 47-58.

Franco, C.M.M., P.P. Michelsen and Oades J.M. 2000b. Amelioration of water repellency: application of slow-release fertilizers to stimulate microbial breakdown of waxes. $J$. Hydro., 231/232: 342-351.

Gniwotta, F., G. Vogg, V. Gartmann, T.L.W. Carver, M. Riederer and Jetter, R. 2005. What do microbes encounter at the plant surface: chemical composition of pea leaf cuticular waxes. Plant Physiol., 139: 519530.

Haba, E., O. Bresco, C. Ferrer, A. Marqués, M. Busquets and Manresa A..2000. Isolation of lipase-secreting bacteria by deploying frying oil as selective substrate. Enzyme Microb. Technol., 26: 40-44.

Hallett, P.D. 2008. A Brief Overview of the Causes, Impacts and Amelioration of Soil Water Repellency - a Review. Soil Water Res., 3(Special Issue 1): S21-S29.

Hamilton, R.J. 1995. Waxes: Chemistry, molecular biology and functions, The oily press, Dundee. 117.

Huang, D., J. Zhang, F. Song and Lang. 2007 Z.Microbial control and biotechnology research on Bacillus thuringiensis in China. J. Invertebr. Pathol., 95:175-180.

Husain, D.R., M., Goutx, C., Bezac, M., Gilewicz, Bertrand, J.C. 1997. Morphological adaptation of Pseudomonas naufica strain 617 to growth on eicosane and modes of eicosane uptake. Lett. Appl. Microbiol., 24: 55-58.

Ishige, T., A. Tani, Y. Sakai and Kato N.2003. Wax ester production by bacteria. Curr. Opin. Microbiol., 6(3): 244-250.

Ivanov, A.G. and Angelov M.N. 1997. 
Photosynthesis response to triacontanol correlates with increased dynamics of mesophyll protoplast and chloroplast membranes. Plant Growth Regul., 21: 145152.

Kocha, K., K.D. Hartmannb, L. Schreiberb, W. Barthlotta and Neinhuisc C.2005. Influences of air humidity during the cultivation of plants on wax chemical composition, morphology and leaf surface wettability. Plant Physiol., 139: 519-530.

Kolattukudy, P.E. and Walton, T.J. 1973. The biochemistry of plant cuticular lipids. In: The Chemistry of Fats and Other Lipids (Ed.) R.T. Holmam. Pergamon Press, Oxford, Pp. 121-125.

Kolattukudy, P.E., R. Croteau and Buckner, J.S. 1976. Biochemistry of plant waxes. In: Chemistry and biochemistry of natural waxes (Ed): P.E. Kolattukudy. ElSevier, Amsterdam, Pp. 289-347.

Kumar, G., R. Kumar and Sharma, A. 2015. Characterization of biosurfactants from indigenous soil bacteria recovered from oil contaminated sites. J. Environ. Biol., 36: 1101-1104.

Lynch, J.M. and Hobbie J.E. 1988. Microflora of aerial plants parts. In: Concepts and applications in Microbial Ecology (Eds) J.M. Lynch and J.E. Hobbie. Blackwell Scientific Publishers. Oxford, Pp. 222-230.

Markossian, S., P. Becker, H. Markl and Antranikian, G. 2008. Isolation and characterization of lipid-degrading Bacillus thermoleovorans IHI-91 from an icelandic hot spring. Biores. Technol., 107: 485-490.

Mendonsa, E.S., P.H. Vartak, J.U. Rao and Deshpande M.V. 1996. An enzyme from Myrothecium verrucaria that degrades insect cuticles for biocontrol of Aedes aegypti mosquito. Biotechnol. Lett., 18(4): 373-376.

Morley, C.P., K.A. Mainwaring, S.H. Doerr, P.C. Douglas, T. Llewellyn and Dekker L.W. 2005. Organic compounds at different depths in a sandy soil and their role in water repellency. Aust. J. Soil Res., 43: 239-249.

Morrison, W.H., D.E., Akin and Robertson J. 1981. Open pollinated and hybrid sunflower seed structures that may affect processing for oil. J. Ame. Oil Chem. Soc., 58: 969- 972.

Nelson, D. R., C.L. Fatland, J.S. Buckner and
Freeman T.P. 1999. External lipids of adults of the giant whitefly, Aleurodicus dugesii. Comp. Biochem. Physiol., 123(2): 137-145.

Nicolau, J.M., A. Sole, J. Puigdefabregas and Gutierrez L. 1996. Effects of soil and vegetation on runoff along a catena in semiarid Spain. Geomorphol., 14: 297-309.

NRCS (National Resource Conservation Service). 2000. Soil organic matter notes, viewed $26^{\text {th }}$ June 2007.

Nguyen, S. H., H. K. Webb, P. J. Mahon, R. J. Crawford and Ivanova E. P.. 2014. Natural insect and plant micro-/nano structured surfaces: An excellent selection of valuable templates with super hydrophobic and selfcleaning properties. Mol., 19: 13614-13630.

Oerke, E.C. and Dehne, H.W. 2004. Safeguarding production - losses in major crops and the role of crop protection. Crop Prot., 23: 275285.

Ortwin, G., K. Christian, D. Michael, B. Gerhard and Reinhard J. 2005. Surface composition of myrmecophilic plants: cuticular wax and glandular trichomes on leaves of Macaranga tanarius. J. Chemical Eco., 31: 23-41.

Patel, D., P.R. Thakor and Lakshmi B.2015. Role of Leifsonia sp. in degradation of Paraffin. Int. J. Innov. Res. Sci. Eng. Technol., 4: 9658-9663.

Perry, J.J. and Scheld, H.W. 1968. Oxidation of hydrocarbons by microorganisms isolated from polluted soil. Can. J. Microbiol. 14: 403-407.

Kumar, R., D. Verma, B. Singh, U. Kumar, and Shweta. 2010. Composting of sugarcane waste by-products through treatment with microorganisms and subsequent vermicomposting. Biores. Technol., 101: 6707-6711.

Ridgway, H.F., J. Safarik, D. Phills and Clark, D. 1990. Identification and catabolic activity of well derived gasoline degrading bacteria from a contaminated aquifer. Appl. Environ. Microbiol., 56: 3565-3575.

Ries, S.K., V.F. Wert, C. Sweelev and Leavitt R.A. 1977. Triacontanol: A new natural occurring plant growth regulator. Sci., 195: 1339-1341.

Ritsema, C.J., L.W. Dekker, E.G.M. Van den Elsen, K. Oostindie and Nieber, J.L. 1997. Recurring fingered flow pathways in a water 
repellent sandy field soil. Hydrol. Earth Syst. Sci., 4: 777-786.

Rocha, C., F. San-blas, G. San-blas and Vierma L. 1992. Biosurfactant production by two isolates of Pseudomonas aeruginosa. World J. Microbiol. Biotechnol., 8:125-128.

Roper, M.M. 2004. The isolation and characterization of bacteria with the potential to degrade waxes that causes water repellency in sandy soils. Aust. J. Soil Res., 42: 427-434.

Roper, M.M. 2005. Managing soils to enhance the potential for bioremediation of water repellency. Aust. J. Soil Res., 43: 803-810.

Ruiz, C.F., I.J. Pastor and Diaz, P. 2004. Isolation of lipid and polysaccharide degrading microorganisms from subtropical forest soil and analysis of lipolytic strain Bacillus sp. CR179. Lett. Appl. Microbiol., 4: 365-371.

Sakthipriya, N., M. Doble and Sangwai J.S..2015. Biosurfactant from Pseudomonas species with waxes as carbon source- Their production, modeling and properties. J. Ind. Eng. Chem., 31: 100-111.

Salunkhe, R., C.D. Patil, B.K. Salunkhe, N.M. Rosas-Garci'a and Patil, S.V. 2013. Effect of wax degrading bacteria on life cycle of the pink hibiscus mealybug, Maconellicoccus hirsutus (Green) (Hemiptera: Pseudococcidae). BioControl, 58: 535-542.

Samanta, R., A.K. Dutta and Sen, S.P. 1986. The utilization of leaf wax by $\mathrm{N}_{2}$-fixing microorganisms on the leaf surface. J. Agri. Sci., 107: 681-685.

Schnitzer, M. and Khan, U.K. 1972. Humic substances in the environment. Marcel Dekker, New York.P 379.

Shaikh, A.J., P.G. Patil and Ambare M.G. 2015. Availability of crop residues in India and their potential uses. Cotton Res J.., 6: 137143.

Shaikh, S.A and Deshpande, M.V. 1993.Chitinolytic enzymes. Their contribution to basic and applied research. World J. Microb. Biot., 9(4): 468-475.

Sharma, A.K., V. Sharma and Saxena, J. 2016. A Review Paper on Properties of Fungal Lipases. Int. J. Curr. Microbiol. App. Sci., 5(12): 123-130.

Singer, M.E.V. and Finnerty W.R. 1990. Physiology of biosurfactant synthesis by Rhodococcus species. Can. J. Microbiol., 36: 741-745.

Stleger, R.J., R.M. Cooper and Charnley, A.K. 1988. Utilization of alkanes by entomopathogenic fungi. J. Invertebr. Pathol., 52: 356-359.

Tomati, U., E. Galli, L. Pasetti and Volterra E. 1995. Bioremediation of olive mill waste waters by composting. Waste Manage. Res., 13: 509-518.

Tulloch, A.P. 1970. The Composition of Beeswax and Other Waxes Secreted by Insects. Lipids, 5(2): 247-258.

Watson, G.W. and Kubiriba, J. 2005. Identification of mealybugs (Hemiptera: Pseudococcidae) on banana and plantain in Africa. African Entomol., 13: 35-47.

Wullschleger, S.D. and Oosterhuis, D.M. 1989. The occurrence of an internal cuticle in cotton (Gossypium hirsutum) leaf stomates. $J$. Environ. Exp. Bot., 29: 229-235.

Xu, J., Y. Zhang, T. Hung and Deng, H. 2013. Growth characteristics of seven hydrocarbondegrading active bacteria isolated from oil contaminated soil. Nat. Env. Poll. Tech., 12(1): 17-24.

\section{How to cite this article:}

Arunkumar, N., J. Gulsar Banu, N. Gopalakrishnan and Prakash, A.H. 2017. Wax Degrading Bacteria: Scope and Applications in Agriculture. Int.J.Curr.Microbiol.App.Sci. 6(2): 649-664. doi: http://dx.doi.org/10.20546/ijcmas.2017.602.074 